\title{
Constitutions, Constitutionalism and the Case of Modern China
}

\author{
Albert H.Y. Chen
}

THE ideas and practices of written constitutions and constitutionalism that originated in the West in the $18^{\text {th }}$ century were first imported into China in the late $19^{\text {th }}$ century. There were three eras of constitution-making in modern Chinese history: the last decade of Qing imperial rule (1901-11), the republican era (1911-1949), and the communist era (1949-). Dr Sun Yat-sen, founding father of the Republic of China (RoC), developed a three-stage theory of the Chinese republic's political development ${ }^{1}$ in which the last stage was to be constitutionalism (xianzheng). Although China in theory entered this last stage when the RoC Constitution of 1946 was enacted, the civil and political rights in this Constitution became largely suspended as the RoC regime, upon its defeat by the Chinese Communists in the Chinese Civil War of the late 1940s, moved to Taiwan and proclaimed martial law. The establishment of the People's Republic of China (PRC) in the Mainland in 1949 inaugurated a new era of constitution-making under the Soviet Union's influence. However, even today, the discussion of "constitutionalism" (xianzheng) is still discouraged by the PRC regime, ${ }^{2}$ although the concepts of the (socialist) Rule of Law and human rights have been affirmed by constitutional amendments in 1999 and 2004 respectively. $^{3}$

This chapter will first review the historical evolution of constitutions and

\footnotetext{
- This chapter draws on the following of the author's previous works: 'Pathways of Western liberal constitutional development in Asia: A comparative study of five major nations' (2010) 8 International Journal of Constitutional Law 849-884; 'Constitutionalism and constitutional change in East and Southeast Asia: a historical and comparative overview', in Albert H.Y. Chen and Tom Ginsburg (eds), Public Law in East Asia (Ashgate, 2013), xv-xlvii; 'The achievement of constitutionalism in Asia: Moving beyond "constitutions without constitutionalism", in Albert H.Y. Chen (ed), Constitutionalism in Asia in the Early Twenty-First Century (Cambridge U Press, 2014), 1-31; 'The discourse of political constitutionalism in contemporary China' (2014) 14 (2) China Review 183-214; 'Western constitutionalism in Southeast Asia: Some historical and comparative observations', in Dirk Ehlers et al. (eds), Constitutionalism and Good Governance: Eastern and Western Perspectives (Nomos, 2014) 63-80; 'China's long march towards rule of law or China's turn against law?' (2016) 4(1) Chinese Journal of Comparative Law 1-35; 'Constitutions, constitutional practice and constitutionalism in East Asia', in Christoph Antons (ed), Routledge Handbook of Asian Law (Routledge, 2017), 75-93.

1 The three stages were military rule, "political tutelage" and "constitutional government" (xianzheng in Chinese, alternatively translated as "constitutionalism"). See n 57 below.

2 See Rogier Creemers, 'China's Constitutionalism Debate: Content, Context and Implications' (2015) 74 China Journal 91-109; Thomas E. Kellogg, 'Arguing Chinese constitutionalism: The 2013 constitutional debate and the "urgency" of political reform' (2016) 11 U.Pa. Asian L.Rev. 337-407; Lance L.P. Gore, 'The Political Limits to Judicial Reform in China' (2014) 2 Chinese Journal of Comparative Law 213-232, at 214-220.

${ }^{3}$ See Albert H.Y. Chen, An Introduction to the Legal System of the People's Republic of China (Hong Kong: LexisNexis, $4^{\text {th }}$ ed. 2011) 56-58.
} 
constitutionalism in the modern world (part I), and consider possible typologies of constitutions and constitutionalism in the contemporary world (part II). It then introduces the historical and ideological contexts of constitutional developments in modern China, and describes the operation of the Chinese constitutional system (part III). Finally, it considers whether or to what extent, or what type (if any) of, constitutionalism is practised in contemporary China (part IV).

\section{The rise and globalization of constitutions and constitutionalism}

The modern idea of a written "constitution", meaning "a frame of political society, organized through and by the law, for the purpose of restraining arbitrary power", 4 was first well-developed in the course of the American and French Revolutions. The constitution has been conceived as a fundamental written law which simultaneously establishes the governmental system of a state and regulates the exercise of political power within the system. The constitution constitutes the state and its government; the government derives its legitimacy and authority from the constitution. The people of the nation-state are the makers of the constitution, acting directly or through their representatives in a constituent assembly. This is the theory of the constituent power, as distinguished from the government power which is constituted by the constitution. The exercise of the constituent power by the people is a manifestation of the sovereignty of the people, a fundamental concept that underlies most constitutions of modern times all over the world. ${ }^{5}$

In terms of their substantive content, modern constitutions can be understood as attempts by their draftsmen to design rationally a form of government that can best serve the objectives of the nation-state. The draftsmen of the first modern constitutions devised schemes of government for the purpose of minimizing the possibility of abuse of political power, tyranny or oppression, and maximizing the protection of political freedom and the individual's rights to life, liberty and property. Hence principles and institutions such as the Rule of Law, separation of powers, checks and balances, parliamentary elections and judicial independence were written into constitutions. Bills of rights ${ }^{6}$ were also promulgated to provide for citizens' rights and freedoms which governments must respect.

After the birth of the first modern constitutions in the USA and France, the

\footnotetext{
4 Giovanni Sartori, 'Constitutionalism: a preliminary discussion' (1962) 56(4) American Political Science Review 853 at 860 (emphasis in original).

5 See generally Dieter Grimm, 'Types of constitutions', in Michel Rosenfeld and András Sajó (eds), Oxford Handbook of Comparative Constitutional Law (Oxford U Press, 2012) 98 at 101-105; Martin Loughlin, 'What is constitutionalism?' in Petra Dobner and Martin Loughlin (eds), The Twilight of Constitutionalism (Oxford U Press, 2010) 47-72.

${ }^{6}$ Such as the French Declaration of the Rights of Man and the Citizen (1789) and the Bill of Rights inserted into the Constitution of the USA in 1791.
} 
practice of constitution-making quickly spread throughout Europe in the course of the nineteenth century, and then all over the world in the course of the twentieth century. In today's world, the possession of a constitution seems to have been accepted by all as a hallmark of the legitimacy of a nation-state and its regime for both domestic and external purposes. However, "once invented the constitution could be instrumentalized for purposes other than the original ones, adopted only in part or even as a mere form". 7

Unlike the earlier Western constitutions, the first constitutions adopted by regimes in the non-Western world were not enacted after a revolution in order to constitute a new state and a new political order, nor inspired by the liberal doctrine of the protection of individuals' rights. Instead, such later constitutions were designed to bolster the legitimacy of regimes threatened by Western powers and to enhance the effectiveness of the former's rule, although they did have the effect of modifying the existing political structure by introducing Western-style institutions such as parliaments and elections. Such constitutions are "politically enabling documents": 8 instead of aiming at the limitation and control of government, they were promulgated by the existing regime to enable itself to be more legitimate and more effective, and thus more capable of survival when faced with domestic and external challenges. Examples include the Ottoman Empire's constitution of 1876, the Egyptian constitution of 1882, and the constitution promulgated by the Meiji Emperor of Japan in 1889. As discussed below, the Qing Empire in China also attempted to move towards a constitutional monarchy in the early twentieth century, but was overthrown by the 1911 Revolution before the constitutional reforms could materialise.

The Meiji Constitution was modelled on the Prussian Constitution of $1850 .^{9}$ Although the movement of constitution-making engulfed European states - as well as the newly independent states in Latin America -- in the nineteenth century, there was not yet a uniform practice of enshrining citizens' rights in constitutions, which were primarily documents defining the structure of government and the division of powers between various state organs. For example, neither the Bismarkian federal constitution of Germany enacted in 1871 nor the 1875 constitution of the Third Republic in France included a bill of rights. ${ }^{10}$ And constitutionalism in Europe in the nineteenth century suffered reversals and setbacks in the course of the twentieth century, with the Bolshevik Revolution in Russia in 1917 and the rise of Nazism and

\footnotetext{
7 Grimm, 'Types of constitutions' (n 5 above) at 105.

${ }^{8}$ Nathan J. Brown, 'Regime reinventing themselves: Constitutional development in the Arab world', in Saïd Amir Arjomand (ed.), Constitutionalism and Political Reconstruction (Leiden: Brill, 2007) 47 at $49,67$.

${ }^{9}$ Hiroshi Oda, Japanese Law (London: Butterworths, 1992) 28.

${ }^{10}$ See the discussion in Karl Loewenstein, Political Power and the Governmental Process (U of Chicago Press, 1957) 142-3.
} 
Fascism in Germany and Italy.

The terror and atrocities of the Second World War prompted deeper reflections on constitutionalism, what it requires and how it can be sustained. As a result, what has been termed the "post-War constitutional paradigm" came into existence, ${ }^{11}$ in which respect for human dignity and equality came to be recognised as the core value of the modern constitutional state. This paradigm was exemplified by the German Basic Law of 1949, which affirms the inviolability of human dignity, declares the basic principles of the liberal democratic order and the basic rights of individuals, and establishes a Federal Constitutional Court exercising the power of judicial review as guardian of the constitution and the "objective value order" affirmed by it. ${ }^{12}$

The end of the Second World War and the decolonization of Asia and Africa that followed gave rise to many new states in the international community. The exercise of constitution-making proved to be useful for the founders of the new states.

Constitutions declared their newly acquired sovereignty and independence, and served as a symbol of nationhood and the unity and collective identity of the people of the new state. This wave of constitution-making is an illustration of "constitutional learning" at work. ${ }^{13}$

In this process, the idea of a "constitution", which indigenous leaders of the colonised peoples had learnt from the metropolitan powers, was now used to put an end to colonialism and to proclaim the independence, liberation and empowerment of a new political community. But the widespread adoption of the Western practice of constitution-making by newly independent states in Asia and Africa does not necessarily mean that the new constitutions were intended to serve the same functions and purposes as the first generation of Western constitutions or the contemporary "post-War constitutional paradigm" in the Western world, such as the legal limitation of state power, checks and balances among state organs, and the defence of citizens' rights against the state. For political scientists and scholars of comparative constitutional law, therefore, the challenge is to understand and distinguish the different purposes or functions which constitutions have served, ${ }^{14}$ and the different kinds of constitutions or constitutionalism which have come into existence since the modern idea of the constitution was born in the late eighteenth century.

\footnotetext{
11 Lorraine E. Weinrib, 'The postwar paradigm and American exceptionalism', in Sujit Choudhry (ed.), The Migration of Constitutional Ideas (Cambridge U Press, 2006) 84-112.

12 See Weinrib, ibid.

13 For constitutional learning theory, see David S. Law and Mila Versteeg, 'The evolution and ideology of global constitutionalism' (2011) 99 (5) California Law Review 1163 at 1173-1175.

${ }^{14}$ See, e.g., the discussion of the functions of constitutions in Cheryl Saunders, 'The impact of internationalisation on national constitutions', in Albert H.Y. Chen (ed.), Constitutionalism in Asia in the Early Twenty-First Century (Cambridge U Press, 2014) 391 at 401-402; Tom Ginsburg and Alberto Simpser (eds), Constitutions in Authoritarian Regimes (Cambridge U Press, 2014).
} 


\section{Typologies or classifications of constitutions and constitutionalism}

In The Morality of Law, ${ }^{15}$ Lon Fuller describes the morality of law as a kind of "morality of aspiration". ${ }^{16}$ Such a morality is concerned with the striving to achieve a particular good that can be realized in different degrees. The higher is the degree to which the good is achieved, the more successful and excellent is the moral project concerned. The project of law is the project of subjecting human conduct to the governance of legal rules. Fuller develops eight principles, which he calls the principles of the internal morality of law, as criteria for evaluating the success of this project.

The concept of the morality of law as a morality of aspiration may be usefully applied to understand the project of constitutionalism. Whereas Fuller conceives of the project of the rule of law as one to regulate human behaviour by legal norms, the project of constitutionalism seeks to subject rulers or government to the governance of constitutional and legal rules, to limit their powers and discretions by such rules, and to control and regulate the exercise of such powers and discretions by means of such rules. As in the case of the rule of law, constitutionalism may also be achieved to varying extents.

The extent to which constitutionalism is achieved or practised in a particular state depends significantly on the extent to which the rulers, political leaders or power-holders in that state adopt what H.L.A. Hart ${ }^{17}$ calls the "internal point of view" towards the norms set out in the constitution (the "large-C" Constitution) and the constitutional law of the state (or what has been called "small-c" constitution or constitutional rules) ${ }^{18}$ - recognizing, accepting and "internalizing" such norms as rules of political behavior that they ought to comply with, and as public standards by which their words and deeds are to be judged, and, in cases of violations, may be criticized and subject to sanctions. Where officials and power-holders adopt such an internal point of view towards constitutional norms, it is likely that they will act and exercise powers in accordance with such norms, with the consequence that the constitution will be more fully implemented in practice and constitutionalism will be more fully achieved.

The practice of constitutionalism is not only a matter of degree; it may also be argued that there are different species or types of constitutionalism, "constitution[alism]"19 or political-legal practices relating to constitutions. These

\footnotetext{
15 Lon L. Fuller, The Morality of Law (Yale U Press, rev. ed. 1969).

16 Ibid., at 4.

17 H.L.A. Hart, The Concept of Law (Clarendon Press, 1961).

18 David S. Law, 'Constitutions', in Peter Cane and Herbert Kritzer (eds), Oxford Handbook of Empirical Legal Research (Oxford U Press, 2010) 376 at 377.

19 Wen-Chen Chang and David S. Law, 'Chinese constitutionalism: an oxymoron?', in Gary Jacobsohn
} 
different species of constitutionalism have been shaped by different historical and ideological contexts and traditions, and may be regarded as adaptations of the original idea of constitutionalism to different societies and cultures and their circumstances and needs. Typologies or classifications of constitutions and constitutionalism, which we will now consider, can facilitate the study of different species of constitutionalism. We begin with the classic classifications of constitutions developed by Loewenstein and Sartori.

Loewenstein and Sartori's classifications of constitutions. Loewenstein proposes an "ontological" approach to the classification of constitutions, ${ }^{20}$ which focuses on the degree to which political practice conforms to or relates to the norms set out in the constitution. In his theory, there are three types of constitutions: normative, nominal and semantic. A constitution is normative if it is "faithfully observed by all concerned" and is effective in "governing the dynamics of the power process". 21 A constitution is said to be nominal if it is "not lived up to in practice" because of, for example, unfavourable "socioeconomic conditions", but it serves an "educational" purpose and function, "with the goal, in the near or distant future, of becoming fully normative". ${ }^{22}$ According to Loewenstein, this type of constitutions is often found in "states where western democratic constitutionalism has been implanted into a colonial or feudal-agrarian social order". ${ }^{23}$ The semantic constitution, which in Lowenstein's view was exemplified by that of the former Soviet Union, does provide information about the political and legal systems, but is no more than an instrument of political control and "the formalization of the existing location of political power". "The peaceful, non-revolutionary change in the location of political power is impossible." 24

Sartori also developed a threefold classification of constitutions, ${ }^{25}$ but the terms he used and their meaning are slightly different from Loewenstein's. In Sartori's theory, the three types of constitution are the "garantiste constitution", the "nominal constitution", and the "façade constitution (or fake constitution)". The garantiste constitution secures civil liberties, restricts arbitrary power and ensures a limited government. ${ }^{26}$ It is therefore equivalent to Loewenstein's normative constitution. Satori's nominal constitution is, as Satori himself acknowledges, the same as Loewenstein's semantic constitution. It is a "collection of rules which

and Miguel Schor (eds), Comparative Constitutional Theory (Edward Elgar, forthcoming), http://ssrn.com/abstract=2971724 (May 21, 2017) at 8.

${ }^{20}$ Loewenstein, Political Power (n 10 above).

21 Ibid., at 148-149.

22 Ibid.

23 Ibid., at 151.

24 Ibid., at 149-150.

25 Sartori, 'Constitutionalism' (n 4 above).

26 Ibid., at 854-855. 
organize but do not restrain the exercise of political power". ${ }^{27}$ The main discrepancy between Satori's scheme and Loewenstein's lies in Sartori's concept of the façade constitution, which "give[s] us no reliable information about the real governmental process" and is "basically a disguise" ${ }^{28}$ Façade constitutions "take the appearance of "true constitutions", but "are disregarded (at least in their essential garantiste features)". "As far as the techniques of liberty and the rights of the power addressees are concerned, they are a dead letter." 29 Sartori considered his concept of the façade constitution to be different from Loewenstein's nominal constitution, which (in Loewenstein's view) is intended to become fully normative at some future point in time. Sartori also pointed out that there is "often a considerable overlapping between nominal and façade constitutions", thus giving rise to " a 'mixed type' (partly nominal and partly fake) of pseudo-constitution". 30

The typologies or classifications of constitutions developed by Loewenstein and Sartori may be correlated with the typology or classification of political regimes developed by political scientists. We now review the latter typology and then explore the correlation between the latter and the former typologies.

Types of political regimes. Political regimes in the contemporary world may be classified as democratic, non-democratic (or authoritarian), and hybrid regimes (which have both democratic and authoritarian elements). ${ }^{31}$ Hybrid regimes are also known as semi-authoritarian regimes ${ }^{32}$ or semidemocracy. ${ }^{33}$

The key feature of semi-authoritarianism, as in the cases of Eygpt under Mubarak and Venezuela under Chávez, is that although there exist opposition political parties and elections, there is "little real competition for power", 34 because there are "mechanisms that effectively prevent the transfer of power through elections from the hands of the incumbent leaders or party to a new political elite or organization". ${ }^{35}$ Semi-authoritarianism usually relies on "power networks independent of the formal democratic processes and institutions". ${ }^{36}$ The latter are often weak and manipulated

27 Ibid., at 861 .

28 Ibid.

29 Ibid.

30 Ibid.

31 See, e.g., Larry Diamond, 'Thinking about hybrid regimes' (2002) 13(2) Journal of Democracy 21. Several species of hybrid regimes have been identified, including "semidemocracy", the "hegemonic party system", and "pseudodemocracy": see L. Diamond, J.J. Linz and S.M. Lipset (eds), Politics in Developing Countries (Boulder: Lynne Rienner, 1990), at 7-8.

${ }^{32}$ Marina Ottaway, Democracy Challenged: The Rise of Semi-Authoritarianism (Washington, D.C.: Carnegie Endowment for International Peace, 2003).

${ }^{33}$ William Case, "Can the "halfway house" stand? Semidemocracy and elite theory in three Southeast Asian countries' (1996) 28(4) Comparative Politics 437; William Case, Politics in Southeast Asia (Richmond: Curzon, 2002).

${ }^{34}$ Ottaway, Democracy Challenged (n 32 above) 3.

35 Ibid., at 15.

36 Ibid., at 134. 
by the rulers. ${ }^{37}$ There is thus a "discrepancy between the way in which power is generated and allocated in practice and the way in which it ought to be generated and allocated according to the formal institutional framework". ${ }^{38}$

The concept of semi-authoritarianism overlaps considerably with that of "semidemocracy", which has been used to study the politics of Singapore and Malaysia. ${ }^{39}$ Semidemocracy is characterized by "electoral contestation" without "liberal participation". 40 Restrictions on civil liberties and on the opposition's activities are such that the opposition would not be able to win power in an election, which is no more than a "visible outlet for social grievances". 41

The key distinction between a hybrid regime and a full democracy is that in the former case, although different political parties are allowed to exist and regular elections are held, the possibility of different political parties taking turns to form the government after winning a general election is largely or completely ruled out in practice. The monopoly of power by the ruling elite, or the practical impossibility of transfer of power to a different political party or group, is secured by restrictions on civil and political liberties, persecution of and coercion against opposition politicians (for example, by means of repressive laws or selective enforcement of the law), informal power networks (including those based on a culture of patrimonialism, patronage and clientalism), practices inconsistent with free and fair elections (including vote-buying, rigging the election), etc. On the other hand, the difference between a hybrid regime and a completely authoritarian one is that in the latter case, there exist minimal or no civil and political liberties, little or no space for political and social pluralism (such as political parties other than the ruling party, and civil society organizations outside the control of the regime), and elections (if they exist) are merely those in which there are no candidates who are not from or approved by the ruling party.

Correlation between regime types and types of constitutions. The differences between democratic, authoritarian and hybrid regimes as discussed above have important implications for their constitutions and constitutional practice. The types of constitutions as formulated by Loewenstein and Sartori may be mapped onto the types of regimes as follows. Democratic regimes that are governed by liberal-democratic constitutions have normative or garantiste constitutions. Such constitutions may also operate to varying degrees in democracies that are fragile, unstable, unconsolidated or of poor quality. ${ }^{42}$ On the other hand, transitional or new democratic regimes which

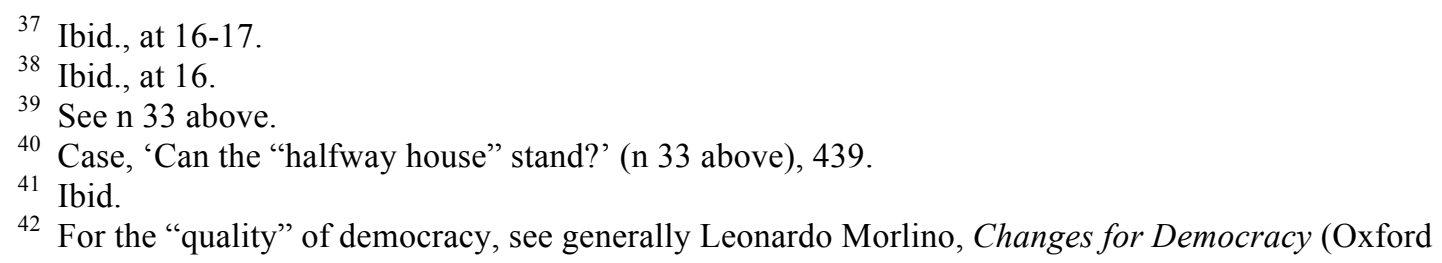


have enacted liberal-democratic constitutions and are aspiring towards the full practice of democracy may have nominal constitutions in Loewenstein's sense. Authoritarian and hybrid regimes which have constitutions that are textually liberal-democratic are likely to have what Sartori calls a façade constitution or pseudo-constitution. Authoritarian or totalitarian regimes of the Marxist-Leninist type, in which the leadership of the communist party is prescribed by the constitution which also rejects multi-party competitive elections, may be said to have semantic constitutions (in Loewenstein's sense) or nominal constitutions (in Sartori's sense). 
Table 1: Types of regimes and constitutions

\begin{tabular}{|l|l|}
\hline Types of regimes & Types of constitutions \\
\hline Democratic & Normative (Loewenstein) or Garantiste (Sartori) \\
\hline Transitional (towards democracy) & Nominal (Loewenstein) \\
\hline Hybrid & Façade (Sartori) or Pseudo-constitution (Sartori) \\
\hline Authoritarian & Façade (Sartori) or Pseudo-constitution (Sartori) \\
\hline Authoritarian (communist) & Semantic (Loewenstein) or Nominal (Sartori) \\
\hline Totalitarian (communist) & Semantic (Loewenstein) or Nominal (Sartori) \\
\hline
\end{tabular}

A three-fold classification. An alternative approach to the classification of constitutions and of political, constitutional and legal practices relating to constitutions is the following three-fold classification which is closely related to the classification of regime types: ${ }^{43}$ (a) constitutionalism in its classical sense or liberal constitutionalism; (b) the Marxist-Leninist mode of governance by a communist party-state legitimized by a written constitution, or communist/socialist constitutional practice; and (c) hybrid constitutionalism, "practised in states in which both elements of liberal constitutionalism and authoritarian elements that subvert or are inconsistent with such constitutionalism exist". ${ }^{44}$ The three categories may be elaborated as follows.

(a) Liberal constitutionalism is the original form of constitutionalism as it first emerged in modern Western history. ${ }^{45}$ This includes elements such as (1) the Rule of Law, (2) the separation of powers, (3) political checks and balances, (4) civil liberties and human rights, (5) a written constitution which operates as a normative constitution (as mentioned above), (6) judicial review of the constitutionality of governmental and legislative acts, and (7) peaceful transfer of political power in accordance with constitutional norms. In the contemporary world, this kind of constitutionalism is basically co-extensive with liberal democracy, although the first constitutional states in Western history were not yet fully democratic.

(b) Communist/socialist constitutional practice is a form of totalitarian or authoritarian rule by a communist Party-State legitimized by a written constitution defining the structure of the state and declaring the rights of citizens. It may be doubted whether it is a genuine form of constitutionalism,

\footnotetext{
43 Chen, 'Pathways of Western liberal constitutional development in Asia' (author's note * on the first page of this chapter) at 880; Chen, 'Constitutionalism and constitutional change in East and Southeast Asia' (also author's note * above) at xvi-xvii.

${ }^{44}$ Chen, 'Constitutionalism and constitutional change' (ibid.), at xvii.

45 See generally Carlos Santiago Nino, The Constitution of Deliberative Democracy (Yale U Press, 1996).
} 
as the power of the communist party may not be subject to such a degree of constitutional and legal restraint that deserves to be called constitutionalism. Hence the term "communist/socialist constitutional practice" rather than "communist/socialist constitutionalism". Whether China in the post-Mao era of economic and legal reforms is moving towards some form of constitutionalism that deserves to be called "communist/socialist constitutionalism" or "party-state constitutionalism" will be discussed below.

(c) Hybrid constitutionalism is a concept analogous to that of "hybrid regimes" as discussed above. It is practised in states with constitutions that are textually liberal-democratic, in which there exist authoritarian practices that are inconsistent with liberal constitutionalism. Such authoritarian practices may be derived from traditional or indigenous notions, norms, institutions and practices of politics, culture and religion (as in theocracy), or constitute deliberate attempts by rulers or ruling elites (such as a one-man dictatorship, one-party hegemony, military regime or theocracy) to practise authoritarian rule behind a façade of liberal-democratic constitutional forms. They may do so by, for example, determining who may participate in elections, manipulating or rigging electoral and other constitutional processes, violating human rights guaranteed by the constitution, or otherwise denying opposition forces fair opportunities to compete for political power on a level playing ground in accordance with the constitution. This concept of hybrid constitutionalism overlaps with or embraces several other types of constitutionalism theorised by contemporary scholars, such as "authoritarian constitutionalism", 46 "communitarian constitutionalism", 47 and "theocratic constitutionalism". 48

This three-fold scheme of classification may be mapped onto Loewenstein's and Sartori's schemes as follows. Liberal constitutionalism corresponds to Loewenstein's "normative constitution" or Sartori's "garantiste constitution". Communist/socialist constitutional practice would be partly based on what Loewenstein calls a "semantic constitution" or what Sartori calls a "nominal constitution", and partly on Sartori's "façade constitutions" and "mixed type of pseudo-constitution". And hybrid constitutionalism would be some kind of mixture (in different proportions, thus giving rise to different versions of hybrid constitutionalism, some closer to liberal

\footnotetext{
46 Mark Tushnet, 'Authoritarian constitutionalism' (2015) 100 Cornell L.Rev. 391; Tom Ginsburg and Alberto Simpser (eds), Constitutions in Authoritarian Regimes (Cambridge U Press, 2014).

47 Li-ann Thio, 'Constitutionalism in illiberal polities', in Rosenfeld and Sajó (eds), Oxford Handbook of Comparative Constitutional Law (n 5 above) 133 at 142-147.

48 Thio, ibid., at 138-142; Larry C. Backer, 'God(s) over constitutions: International and religious transnational constitutionalism in the $21^{\text {st }}$ century’ (2007) 27 Mississippi College L.Rev. 11.
} 
constitionalism and some further away from it) of certain characteristics of each of the three types of constitutions in either Loewenstein's typology or Sartori's. The following chart shows the correlation between the three species of constitutionalism and the types of constitutions as formulated by Lowenstein and Sartori:

Table 2: Types of constitutions and constitutionalism

\begin{tabular}{|l|l|l|l|}
\hline \multicolumn{1}{|c|}{$\begin{array}{l}\text { Types of } \\
\text { constitutions }\end{array}$} & $\begin{array}{l}\text { Loewenstein's } \\
\text { nominal const., } \\
\text { Sartori's facade } \\
\text { const. and mixed } \\
\text { type of } \\
\text { pseudo-constitution }\end{array}$ & $\begin{array}{l}\text { Loewenstein's } \\
\text { semantic const. or } \\
\text { Sartori's nominal } \\
\text { constitution } \\
\text { constitutionalism }\end{array}$ & $\begin{array}{l}\text { Lowenstein's } \\
\text { normative const. or } \\
\text { or Sartori's } \\
\text { garantiste } \\
\text { constitution }\end{array}$ \\
\hline Liberal constitutionalism & & $\sqrt{ }$ & \\
\hline $\begin{array}{l}\text { Communist/socialist } \\
\text { constitutional practice }\end{array}$ & $\sqrt{ }$ & $\sqrt{ }$ & $\sqrt{ }$ \\
\hline Hybrid constitutionalism & $\sqrt{ }$ & & \\
\hline
\end{tabular}

A multi-dimensional model to "pluralize" the concept of "constitution[alism]". Whereas the above typologies of constitutions and constitutionalism focus primarily on the relationship between constitutional text and practice, the manner in which the constitution is implemented, and the nature of the political regime in which the constitution operates, another possible approach to the comparative study of constitutions or constitutionalism is to " 'pluraliz[e]' the concept of constitution[alism] into categories or subtypes with criteria of varying thickness". 49 In this theory, the word "constitution[alism]" is used because " 'constitution' and 'constitutionalism' are merely semantic variants of the same concept". 50 According to this theory, three types of criteria may be applied in defining the concept of "constitution[alism]", each of which may be applied either strictly or leniently. The three types of criteria relate respectively to "the stated goals or aspirations" of the regime, "the formal or institutional characteristics of the regime", and the regime's "real-world performance". 51 Thus the assessment of whether "constitution[alism]" exists or the extent to which 'constitution[alism]' is practised in a particular country depends on which of the above types of criteria are used, and also on whether the criteria are applied strictly or leniently. "There is no scholarly consensus capable of supplying us with a single correct definition of constitution[alism]. For better or for worse, scholars

\footnotetext{
${ }^{49}$ Chang and Law, 'Chinese constitutionalism' (n 19 above) at 9.

50 Ibid., at 7.

51 Ibid., at 9-12.
} 
have implicitly or explicitly employed definitions of constitution[alism] that incorporate different combinations of criteria with varying degrees of stringency". 52

\section{Constitutional developments in modern China}

From imperial to republican era. During the last decade of its dynastic rule in China, the Qing court began to move towards a constitutional monarchy. ${ }^{53}$ An "Imperial Constitutional Outline" was promulgated in 1908, and provincial assemblies and a provisional national assembly were elected. ${ }^{54}$ The 1911 Revolution overthrew the Qing Empire, and the Republic of China (RoC) was established in 1912 with a liberal democratic "provisional constitution". 55 This constitution exemplifies what Loewenstein calls the "nominal constitution" - a constitution whose makers intend to implement but fails to be put into practice because of unfavourable political and socioeconomic conditions.

In the first one and a half decade of the republican era, several constitutions were promulgated or drafted by successive governments in Beijing, but none was effective as China was beset with warlordism and civil strife. ${ }^{56}$ In 1928, the Kuomintang (KMT, or Chinese Nationalist Party) under Chiang Kai-shek's leadership succeeded to unify large parts of China (but not areas under the control of the Chinese Communist Party (CCP)) and established a new RoC government in Nanjing. The KMT adhered to the strategy of constitutional development advocated by its founder, Dr Sun Yat-sen, who developed a three-stage programme for China's political transformation. $^{57}$ The first stage was military government (junzheng) for the purpose of ending warlordism and unifying the country by military force. The second was preparation for constitutional democracy under the KMT's political tutelage

\footnotetext{
52 Ibid., at 13.

53 Xiaohong Xiao-Planes, 'Of constitutions and constitutionalism: Trying to build a new political order in China, 1908-1949', in Stéphanie Balme and Michael W. Dowdle (eds), Building Constitutionalism in China (New York: Palgrave Macmillan, 2009) 37-57.

54 Xiaohong Xiao-Plane, 'The first democratic experiment in China (1908-1914): Chinese tradition and local elite practices', in M. D.-M. and P.-É. Will, China, Democracy, and Law: A Historical and Contemporary Approach, transl. by N. Norberg (Leiden: Brill, 2012) 227-256.

55 See generally Wei-tung Pan, The Chinese Constitution: A Study of Forty Years of Constitution-making in China (Westport, Connecticut: Hyperion Press, reprint ed. 1983, orig. pub. 1945).

56 See generally Pan (ibid.); Andrew Nathan, Peking Politics, 1918-1923: Factionalism and the Failure of Constitutionalism (University of California Press, 1976).

57 See generally Sheng Wang, The Thought of Dr Sun Yat-sen (Taipei: Li Ming Cultural Enterprise, 1981); Audrey Wells, The Political Thought of Sun Yat-sen: Development and Impact (Palgrave, 2001); C. C. Tan, Chinese Political Thought in the Twentieth Century (Newton Abbot, Devon: David \& Charles, 1972).
} 
(xunzheng). The third and final stage would be constitutional government (xianzheng). Using our terminology, this may be understood as a theory about establishing "hybrid constitutionalism" first and then moving towards liberal constitutionalism. A provisional constitution for the period of "political tutelage" was promulgated by Chiang's government in 1931. This was known as the Constitution of the RoC in the Period of Political Tutelage (Zhonghua minguo xunzheng shiqi yuefa); it expressly vested political power in the KMT. ${ }^{58}$

After the end of the Sino-Japanese War in 1945 and before civil war soon erupted again between the KMT and the CCP, a new Constitution of the RoC was adopted by a constituent assembly convened by Chiang's government in December $1946 .{ }^{59}$ The original purpose of the making of this Constitution was to move China from the stage of political tutelage by the KMT to full liberal constitutional democracy with a constitutional government based on the separation of powers, elected by free multi-party election and respectful of civil liberties and human rights. The 1946 Constitution exhibits all key ingredients of a liberal democracy, and establishes a constitutional court (consisting of the Grand Justices of the Judicial Yuan). The constitution contains provisions on horizontal and vertical separation of powers, checks and balances, free elections and the guarantee of human rights. However, the constitution was never fully implemented in China as a result of the following events. As China descended into a state of civil war, the KMT-led National Assembly in April 1948 introduced a constitutional amendment known as the "Temporary Provisions for the Period of National Mobilization to Suppress the Communist Rebellion" which expanded the emergency powers of the President. Jieyan (which may be translated as a state of siege or martial law) was decreed by the KMT government in December 1948 in mainland China and in May 1949 in Taiwan (which had been ceded by the Qing Empire to Japan in 1895 and liberated from Japanese rule in 1945). After its defeat by the Communist forces in the mainland, the KMT government retreated to Taiwan in $1949 .{ }^{60}$

The civil liberties and democratic elections promised by the 1946 Constitution were largely suspended by the RoC regime in Taiwan for nearly four decades, ${ }^{61}$ until

\footnotetext{
58 See Pan, The Chinese Constitution (note 55 above) 48-50, 247-255.

59 See generally Xiao-Planes, 'Of constitutions and constitutionalism' (n 53 above); Jing Jiren, Zhongguo lixian shi (History of Chinese Constitutionalism) (Taipei: Lianjing, 1984), chap. 16; Tuan-sheng Ch'ien, The Government and Politics of China 1912-1949 (Harvard U Press, 1950).

${ }^{60}$ On the history of Taiwan, see generally Murray A. Rubinstein (ed), Taiwan: A New History (Armonk, New York: M.E. Sharpe, 1999); John F. Copper, Taiwan: Nation-State or Province? (Boulder: Westview Press, $3^{\text {rd }}$ ed. 1999); Denny Roy, Taiwan: A Political History (Ithaca: Cornell University Press, 2003).

${ }^{61}$ See generally Hungdah Chiu, 'Constitutional Development in the Republic of China in Taiwan', in Steve Tsang (ed), In the Shadow of China: Political Developments in Taiwan Since 1949 (Hong Kong University Press, 1993), chap. 1; Chi-tung Lin and Herbert H.P. Ma, 'The Republic of China (Taiwan)', in Lawrence W. Beer (ed.), Constitutional Systems in Late Twentieth Century Asia (Seattle: University
} 
the liberalisation and democratization of the regime that began with the lifting of martial law in $1987 .{ }^{62}$ The case of Taiwan thus exemplifies a transition from hybrid constitutionalism to liberal constitutionalism.

The PRC Constitution. After defeating the KMT forces, the CCP under Mao Zedong's leadership established the new People's Republic of China (PRC) in October $1949 .^{63}$ In the first few years of the new regime, China was governed by a provisional constitution known as the "Common Programme of the Chinese People's Political Consultative Conference". The first constitution of the PRC was adopted by a new National People's Congress in $1954 .{ }^{64}$ This constitution was to a considerable extent modeled on the 1936 Constitution of the U.S.S.R., ${ }^{65}$ although the ROC Constitution was included among the reference materials compiled for some of those involved in the drafting exercise. ${ }^{66}$

The second constitution was enacted in 1975 when the PRC was under the "ultra-leftist" rule that began with the launch of the "Great Proletarian Cultural Revolution" in 1966. This constitution codified the ideology of the Cultural Revolution era. The "Cultural Revolution" was a mass movement instigated by Mao Zedong to purge those considered to be "capitalist roaders" in the CCP and other "class enemies" in Chinese society. Ideologically indoctrinated by the personality cult of Mao, young "Red Guards" resorted to large-scale violence and terror in "struggling against" officials, intellectuals and ordinary people accused of being counter-revolutionaries. ${ }^{67}$

The third constitution, introduced two years after Mao's death in 1976, marked the beginnings of the retreat from Maoism and the new orientation of "socialist modernization". The fourth constitution, which (subject to several amendments) is still in force today, was enacted in 1982. It laid the ideological, institutional and legal foundations for Deng Xiaoping's era of "reform and opening", and has served as the constitutional embodiment of Deng's doctrine of "socialism with Chinese

of Washington Press, 1992) 88.

${ }^{62}$ See generally Linda Chao and Ramon H. Myers, The First Chinese Democracy: Political Life in the Republic of China on Taiwan (Baltimore: Johns Hopkins U Press, 1998).

${ }^{63}$ On the history of the PRC, see, e.g., John K. Fairbank, The Great Chinese Revolution 1800-1975 (New York: Harper \& Row, 1987); Immanuel C.Y. Hsü, The Rise of Modern China (Oxford U Press, 2000); Jonathan Fenby, The Penguin History of Modern China (London: Allen Lane, 2008).

${ }^{64}$ See Glenn D. Tiffert, 'Epistrophy: Chinese constitutionalism and the 1950s', in Balme and Dowdle (eds), Building Constitutionalism in China (n 53 above) 59-76. On the constitutional history of the PRC, see Xu Chongde, Zhonghua renmin gongheguo xianfa shi (Constitutional History of the People's Republic of China) (Fuzhou: Fujian People's Press, 2003).

${ }^{65}$ Albert H.Y. Chen, 'Socialist Law, Civil Law, Common Law, and the Classification of Contemporary Chinese Law', in J.M. Otto et al. (eds), Law-Making in the People's Republic of China (The Hague: Kluwer Law International, 2000) 55, at 57.

${ }^{66}$ Cai Dingjian, Xianfa jingjie (Commentary on the Constitution) (Beijing: Law Press, $2^{\text {nd }}$ ed. 2006) 33.

67 Yu-Shan Wu, 'China', in Jeffrey Kopstein et al. (eds), Comparative Politics (Cambridge U Press, $2^{\text {nd }}$ ed. 2005) 253 at $267-8$. 
characteristics".

The 1982 Constitution was drafted using the 1954 Constitution as the baseline, and sought to improve upon it. The "Four Cardinal Principles" advocated by Deng Xiaoping were often referred to as forming key ingredients of the guiding ideology behind the 1982 Constitution. ${ }^{68}$ Deng had stated that adherence to these four principles was essential for the purpose of pursuing China's economic modernization. ${ }^{69}$ The four principles are insisting on the socialist path, insisting on the people's democratic dictatorship, insisting on the CCP's leadership, and insisting on Marxism-Leninism-Mao Zedong Thought (subsequently revised to include Deng Xiaoping Theory and the idea of the "three represents" $"$ ). These principles may be discerned from a passage in the Preamble to the 1982 Constitution. ${ }^{71}$

Article 1 of the PRC Constitution states that "The PRC is a socialist state under the people's democratic dictatorship led by the working class and based on the alliance of workers and peasants. The socialist system is the basic system of the PRC." "People's democratic dictatorship" is a term coined by Mao Zedong for the purpose of the indigenous application of the Marxist concept of "proletarian dictatorship" which is to be practised after the socialist revolution overthrowing capitalism. ${ }^{72}$ The leadership of the working class mentioned in article 1 of the Constitution is an implicit reference to the leadership of the CCP, as under the Leninist theory of the communist party, this party consists of the vanguard of the proletariat (i.e. the working class) and shall exercise leadership on behalf of the proletariat in building the socialist society. ${ }^{73}$

After the 1982 Constitution was enacted, four sets of amendments to it have been introduced, in 1988, 1993, 1999 and 2004 respectively. The amendments reflect the deepening and strengthening of the policy of "reform and opening", and include, for example, the introduction of the following terms and concepts into the Constitution: the preliminary stage of socialism, socialism with Chinese characteristics, the socialist market economy, protecting the private sector of the economy, ruling the country according to law and building a socialist Rechtsstaat (fazhiguojia in Chinese, or a State based on the Rule of Law), and protecting human rights and private property

\footnotetext{
${ }^{68}$ Cai, Commentary (n 66 above), at 73, 81, 84, 99; Xu, Constitutional History (n 64 above), at 878 (citing Peng Zhen's speech to the National People's Congress when the draft constitution was presented to it).

69 Cai (ibid.) at 73.

${ }^{70}$ Chen, Introduction (n 3 above) at 57-58; Larry C. Backer, 'The rule of law, the Chinese Communist Party, and ideological campaigns: Sange daibiao (the three represents), socialist rule of law, and modern Chinese constitutionalism' (2006) 16(1) Transnational Law and Contemporary Problems 29-102.

${ }_{71}$ See the $7^{\text {th }}$ paragraph of the Preamble.

72 Cai, Commentary (n 66 above) at 10, 92-93.

${ }^{73}$ Ibid., at 161-2.
} 
rights.

The operation of the Chinese constitutional system. Since the Dengist era of "reform and opening" began in the late 1970s, China has moved a long way from a totalitarian communist system in which the Party-State controlled all social, economic and cultural domains and all aspects of citizens' lives, to an authoritarian political system that has committed itself to certain standards of legality ${ }^{74}$ and has fostered the development of a vibrant "socialist market economy" or "socialism with Chinese characteristics" (or what some outside observers have called "capitalism with Chinese characteristics" ${ }^{\prime 75}$ ). The economic reform has sustained the rapid growth of domains of private and economic life outside the direct control of the Party-State. ${ }^{76}$

According to the Constitution, the "supreme organ of state power"77 in the PRC is the National People's Congress, which is elected by provincial people's congresses, which in turn are elected by municipal people's congresses. The municipal people's congresses are elected by county-level people's congresses which are directly elected by the people. In practice, candidates for elections to people's congresses are largely determined by CCP organs, and the National People's Congress is largely a rubber-stamp body under the leadership of the CCP. ${ }^{78}$

In the PRC, the principal means by which the Constitution is implemented is the making and enforcement of laws in accordance with the Constitution. ${ }^{79}$ There has been "constitutional evolution through legislation", particularly in the domains of "vertical and horizontal governmental relations" and "interregional relations" ${ }^{80}$ It has been suggested that "China's top legislature has routinely engaged in interpreting the Constitution during the legislative process, and has already accumulated a rich body of constitutional norms." 81 There has been considerable "moderate constitutional reform of the small-c variety [i.e. "small-c" constitutional rules as distinguished from the "large-C" Constitution], in the form of statutory enactments and administrative

\footnotetext{
${ }^{74}$ See, e.g., Albert H.Y. Chen, 'Toward a legal enlightenment: Discussions in contemporary China on the Rule of Law' (1999) 17 UCLA Pacific Basin Law Journal 125; Randall Peerenboom, China's Long March Toward Rule of Law (Cambridge U Press, 2002).

${ }_{75}$ Yasheng Huang, Capitalism with Chinese Characteristics: Entrepreneurship and the State (Cambridge U Press, 2008).

${ }^{76}$ On China's transition from totalitarianism to authoritarianism, see Wu, 'China' (n 67 above).

77 Constitution of the PRC (1982), art. 57.

78 See generally Jiang Jinsong, The National People's Congress of China (Beijing: Foreign Languages Press, 2003), esp. chap. 7; Li Fan (ed.), Renda daibiao xuanju caozong neimu (Insider Story of Manipulation of Elections of Deputies to People's Congresses) (Hong Kong: Xiafei'er Press, 2009); Yang Guangbin and Li Yuejun, Dangdai Zhongguo zhengzhi zhidu daolun (Introduction to the Contemporary Chinese Political System) (Beijing: China Renmin University Press, 2007), esp. chap. 4.

${ }^{79}$ Zhang Qianfan (ed.), Xianfaxue (Constitutional Law) (Beijing: Peking University Press, $3^{\text {rd }}$ ed. 2015), chap. 3.

${ }^{80}$ Yan Lin, 'Constitutional evolution through legislation: The quiet transformation of China's Constitution' (2015) 13(1) International Journal of Constitutional Law 61-89.

${ }^{81}$ Yan Lin and Tom Ginsburg, 'Constitutional interpretation in lawmaking: China's invisible constitutional enforcement mechanism’ (2015) 63 Am.J.Comp.L. 467 at 469.
} 
practice." ${ }^{, 82}$ The growth of the institutional capacity and strength of the people's congress system, ${ }^{83}$ and the development and regularization of norms in China's "unwritten constitution" 84 (such as unwritten norms governing age of retirement and maximum terms of office of Party leaders, their relationship with State institutions, or the mode of collective leadership at the top level of the Party ${ }^{85}$ ), suggest that there has been a trend towards the formalization and constitutionalization of political life in China.

In the era of "reform and opening", the court system has developed rapidly in terms of size, caseload and the educational qualifications and professionalisation of judges ${ }^{86}$ but it has also been beset with problems of corruption, political interference in judicial decision-making and failure to enforce court judgments in civil cases. ${ }^{87}$ The constitutional function of the Chinese courts is to try cases in accordance with the law. ${ }^{88}$ They have no role to play in interpreting the Constitution and reviewing the constitutionality of legal norms and of administrative actions, ${ }^{89}$ although they do exercise the power of judicial review of the legality of administrative actions. ${ }^{90}$ In 2001, the Supreme People's Court's interpretation in the much publicized Qi Yuling case seemed to suggest that Chinese courts may apply constitutional provisions directly in adjudicating cases, ${ }^{91}$ but the repeal by the Supreme People's Court itself of

${ }^{82}$ Chang and Law, 'Chinese constitutionalism' (n 19 above) at 26.

83 See, e.g., Michael W. Dowdle, 'The constitutional development and operations of the National People's Congress' (1997) 11 Colum.J. Asian L. 3; Robert Benewick, 'Towards a developmental theory of constitutionalism: the Chinese case' (1998) 33(4) Government and Opposition 442-461.

${ }^{84}$ Shigong Jiang, 'Written and unwritten constitutions: A new approach to the study of constitutional government in China' (2010) 36(1) Modern China 12.

${ }^{85} \mathrm{Hu}$ Angang, Zhongguo jiti lingdao tizhi (The System of Collective Leadership in China) (Beijing: Renmin University of China Press, 2013).

86 See, e.g., Bin Liang, The Changing Chinese Legal System, 1978 - Present (New York: Routledge, 2008), chap. 3; Zhu Jingwen (ed), Zhongguo falü fazhan baogao (Chinese Legal Development Report) (Beijing: China Renmin University Press, 2007), chaps. 1, 4.

87 See, e.g., Chen, Introduction (n 3 above), chap. 7; Hualing Fu, 'Putting China's judiciary into perspective: Is it independent, competent, and fair?' in Erik G. Jensen and Thomas C. Heller (eds), Beyond Common Knowledge: Empirical Approaches to the Rule of Law (Stanford U Press, 2003), chap. 6; Benjamin L. Liebman, 'China's Courts: Restricted Reform' (2007) 191 China Quarterly 620; Albert H.Y. Chen, 'China's long march towards rule of law or China's turn against law?' (2016) 4 Chinese Journal of Comparative Law 1-35 at 21-25.

88 See art. 126 of the PRC Constitution (1982).

89 Qianfan Zhang, The Constitution of China: A Contextual Analysis (Hart Publishing, 2012) 173-6; Shucheng Wang, 'Emergence of a dual constitution in transitional China' (2015) 45 Hong Kong Law Journal 819-850 at 825 (referring to the Supreme People's Court's Provisions on Citation of Legal Documents as Laws and Regulations in the Judgments (promulgated in 2009), which exclude the possibility of relying on constitutional provisions in judicial decision-making). See also Guobin Zhu, 'Weak courts, weak rights: Assessing the realisation of constitutional rights in PRC courts' (2013) 43 Hong Kong Law Journal 713-743 (arguing that 'the courts as positive enforcer of the Constitution can still play a limited but important and irreplaceable role in realizing constitutional rights').

90 Zhang, ibid., 162-9; Qianfan Zhang, 'From administrative rule of law to constitutionalism? The changing perspectives of the Chinese public law' (2006) 3 Asia Law Review 47.

${ }^{91}$ See Kui Shen, 'Is it the beginning of the era of the rule of the Constitution? Reinterpreting China's "first constitutional case", (2003) 12 Pacific Rim Law and Policy Journal 199; Zhang, 'From administrative rule of law to constitutionalism?' (n 90 above) at 70-73. 
this interpretation in December $2008^{92}$ has signaled that courts are not permitted to interpret or enforce provisions of the Constitution in their adjudicative work.

The limited or negligible role play by courts in the development of Chinese constitutional law should not however be taken to mean that the Chinese constitution is of no significance. For instance, the Sun Zhigang incident of 2003 and subsequent developments in weiquan ("rights defence") movements in Chinese civil society suggest that the concepts, principles and rights enshrined in the Chinese constitution have been increasingly used by litigants, activists and aggrieved persons, in litigation, social movements as well as public discourse, to fight for justice and for the protection of their constitutional rights against violations by authorities. ${ }^{93}$ This may been termed the development of "popular constitutionalism" "94 "societal constitutionalism". ${ }^{95}$ In the first decade of this century, some "constitutional entrepreneurs" in China have successfully mobilized public opinion and made an impact on legal and policy developments by relying on constitutional norms. ${ }^{96}$ Thus it seems that the PRC Constitution is not merely a "sham constitution - in the sense of a constitution that is simply irrelevant and ignored". ${ }^{97}$ The Constitution might be able to "serve as a constructive irritant" to the regime, ${ }^{98}$ in the sense that "it cannot easily be expelled from the system but instead creates space for a normatively privileged form of discourse that cannot easily be ignored." 99

Understanding the Chinese constitution. There is probably a consensus among both Chinese and Western scholars of Chinese constitutional law that in order to understand the operation of the Chinese political and constitutional system, one must look beyond the state organs prescribed by the PRC Constitution, and examine the role of the CCP in the system and the practical operation of the oft-cited principle of Party leadership. Insofar as the CCP and its organization is governed by its own

\footnotetext{
92 See Thomas E. Kellogg, 'The Constitution in the courtroom', in Margaret Y.K. Woo and Mary Gallagher (eds), Chinese Justice: Civil Dispute Resolution in Contemporary China (Cambridge University Press, 2011), chap. 11.

93 See, e.g., Qianfan Zhang, 'A constitution without constitutionalism? The paths of constitutional development in China' (2010) 8 International Journal of Constitutional Law 950-976. However, some weiquan lawyers have become targets of persecution by the regime: see Eva Pils, China's Human Rights Lawyers: Advocacy and Resistance (Routledge, 2015).

94 Zhang, 'A constitution without constitutionalism?' (ibid.) at 963; Stéphanie Balme, 'Ordinary justice and popular constitutionalism in China', in Balme and Dowdle (eds), Building Constitutionalism in China (n 53 above) 179-198; Randall Peerenboom, 'Social foundations of China's living constitution', in Tom Ginsburg (ed.), Comparative Constitutional Design (Cambridge U Press, 2012) 138-163, at 150.

${ }^{95}$ Baogang He, 'Socialist constitutionalism in contemporary China', in Michael W. Dowdle and Michael A. Wilkinson (eds), Constitutionalism Beyond Liberalism (Cambridge U Press, 2017) 176-194, at 184 .

96 Mark Jia, 'China's constitutional entrepreneurs' (2016) 64 Am.J.Comp.L. 619-675.

97 Chang and Law, 'Chinese constitutionalism' (n 19 above), at 41. For "sham constitutions", see David S. Law and Mila Versteeg, 'Sham constitutions' (2013) 101 California Law Review 863.

${ }_{98}$ Chang and Law, ibid., at 42.

99 Ibid., at 43.
} 
constitution, which is known as the Charter (dangzhang) of the CCP, the PRC may be said to have a "dual constitution" consisting of the PRC Constitution and the CCP Charter. ${ }^{100}$ A leading scholar of the "political constitutionalism" school ${ }^{101}$ in contemporary China has stressed that the principle of Party leadership is actually the foremost fundamental law of the Chinese constitution. ${ }^{102}$ In this context, the Chinese constitution must be taken to mean the constitutional law consisting of both the large-C Constitution and small-c constitutional norms, as the principle of Party leadership of State organs (such as the National People's Congress and local people's congresses, the Central People's Government and local people's governments, courts, procuratorates, etc.) has not been expressly or precisely written into any article of the current Constitution, and is only touched upon in its Preamble. Though not given formal constitutional status by the PRC Constitution, the principle of Party leadership is definitely a core element of China's "living constitution" in today. ${ }^{103}$

The concept of "dual constitution" mentioned above has been employed to describe the nature of the Chinese constitutional system and how it has developed in the post-Mao era. It has been suggested that the legal, political and constitutional reforms in China in the last few decades have led to the emergence of a "dual constitution comprising the Party and the State". ${ }^{104}$ In this dual constitutional framework, there are in effect two sovereign bodies, the CCP and the National People's Congress (NPC). ${ }^{105}$ The NPC is the repository of constitutional legitimacy, ${ }^{106}$ because it is elected by the people in accordance with the PRC Constitution and therefore represents the people. "Through the NPC, the Party sought to integrate the polity and to organise it around the principle of one-party rule. The role of the CPC's [CCP] control over the NPC is crucial since deputies give voluntary assent and support to the CPC". ${ }^{107}$ It is pointed out that the CCP itself "realised that the strengthening of the People's Congress System may be a threat to it if not handled properly." "108 "Ironically, the development of the People's Congress System has

\footnotetext{
100 Wang, 'Emergence of a dual constitution' (n 89 above), at 841.

101 For studies of "political constitutionalism" in contemporary China, see Chen, "The discourse of political constitutionalism in contemporary China' (author's note * on the first page of this chapter).

${ }^{102}$ Chen Duanhong, 'Lun xianfa zuowei guojia de genbenfa yu gaojifa' ('The Constitution as the fundamental law and higher law of the State') (2008) 20(4) Zhongwai faxue (Peking University Law Journal) 485-515.

${ }^{103}$ Xin He, 'The Party's leadership as a living constitution in China' (2012) 42 Hong Kong Law Journal 73-93. See also Jianfu Chen, 'Out of the shadows and back to the future: CPC and law in China' (2016) 24(2) Asia Pacific Law Review 176-201.

104 Wang, 'Emergence of a dual constitution' (n 89 above), at 848.

105 Ibid., at 825, citing Jiang, 'Written and unwritten constitutions' (n 84 above), at 23-4.

106 Wang, 'Emergence of a dual constitution' (n 89 above), at 835; He, 'The Party's leadership' (n 103 above), at 81 .

107 Wang, ibid., at 834-5.

108 Ibid., at 836.
} 
become a thorn in the CPC's side, which cannot be readily removed". ${ }^{109}$

The dual constitution is the outcome of the co-evolution of the State system and of the Party system "interdependently" in the last few decades. ${ }^{110}$ On the one hand, the State system consisting of the People's Congresses at national and local levels, the people's governments, the courts, etc. have been strengthened and given more autonomy in the exercise of their constitutional powers. ${ }^{111}$ In particular, local people's congresses have become more active in exercising supervision over local governments, and on a few occasions they have refused to rubber-stamp Government reports or the Party's nominees for government positions. The court system has also been strengthened by a series of judicial reforms and the policy of "ruling the country according to law". ${ }^{112}$ On the other hand, the Party has "integrate[d] itself into the State through political conventions and self-normalisation". ${ }^{113}$ For example, there is deliberately engineered overlapping membership of the leadership State and Party organs. ${ }^{114}$ Intra-party rules and regulations have been introduced to regulate the internal operation of the Party. ${ }^{115}$

\section{Is China practising or on the way to the practice of constitutionalism}

Although China today is still ruled by a communist party that monopolizes political power and does not permit the multi-party elections that take place in states which practise hybrid or liberal constitutionalism, it has successfully pursued market-oriented economic reforms since the 1980s, opened up Chinese society to Western and global influences, and moved from totalitarianism to some form of authoritarianism. It has in recent decades introduced constitutional revisions and legal reforms, including constitutional recognition of socialist legality or socialist Rule of Law, human rights and private property rights. It has made substantial progress in the construction of a socialist legal system in which detailed laws govern most domains of economic and social activities; State organs and officials are required to exercise their powers in accordance with the law; and systems of courts, procuratorates, lawyers and legal education have been built up for the purpose of operating the legal system effectively. ${ }^{116}$

\footnotetext{
109 Ibid., at 849.

110 Ibid., at 822 .

111 Ibid., at 827-834.

112 Ibid., at 845-6. For further details, see Chen, 'China's long march towards rule of law' (n 87 above).

113 Wang, 'Emergence of a dual constitution' (n 89 above), at 819.

114 Ibid., at $836,839$.

115 Ibid., at 840. For further details, see Xiaodan Zhang, 'Rule of law within the Chinese party-state and its recent tendencies' (2017) 9(2) Hague Journal on the Rule of Law 373-400.

116 See generally Chen, 'China's long march towards rule of law' (n 87 above); Albert H.Y. Chen,
} 
Despite bold calls for liberal-democratic constitutional reforms by small numbers of intellectuals, such as the signatories of "Charter 08" of 2008 in China (led by Liu Xiaobo (1955-2017) who was convicted and jailed as a result but also awarded a Nobel Peace Prize in 2010), ${ }^{117}$ the Party-State has firmly resisted any political reform that might weaken or threaten the Communist Party's monopoly of state power. Although human rights are now enshrined in the Constitution, the courts have no role to play in constitutional adjudication as mentioned above. According to the classification schemes developed by Loewenstein and Sartori discussed above, the constitution of the PRC is apparently a "semantic constitution" (Loewenstein's term) or "nominal constitutions" (Sartori's term) in the sense that it reflects the allocation of power (including the structure of State organs and the principle of the leadership of the communist party) but does not effectively constrain its exercise.

However, given the regime's normative commitment to the Rule of Law and reasonable records in making laws and developing legal institutions in the last four decades, ${ }^{118}$ it may be doubted whether the concepts of "semantic" or "nominal" constitutions are completely adequate in describing and analyzing the nature and character of political-constitutional-legal practice in contemporary China. The question thus arises as to whether China's evolving constitutional practice may be said to constitute a distinctive species of constitutionalism, such as "party-state constitutionalism", alternatively known as "state-party constitutionalism".

State-party constitutionalism in China? The theory of "state-party constitutionalism"119 is premised on a broad understanding of constitutionalism which is not limited to liberal constitutionalism. "Constitutionalism is grounded on the fundamental postulate of rule of law", which "avoid[s] tyranny or despotism by grounding state action in law and by limiting the reach of such lawful state action on the basis of values reflecting the values of the political collective". ${ }^{120}$ Depending on the content of the "legitimating value system" in the state concerned, constitutionalism may take the form of "nationalist constitutionalism", "transnational constitutionalism", "theocratic constitutionalism", "natural law constitutionalism", etc. "[T] hey all share equally in the commitment to the fundamental values of a constitutional order - a rule of law based governance structure grounded in limits on

\footnotetext{
'Legal thought and legal development in the People's Republic of China, 1949-2008', in John Gillespie and Albert H.Y. Chen (eds), Legal Reforms in China and Vietnam (Routledge, 2010), 51-77.

117 Jean-Philippe Béja, H. Fu and E. Pils (eds), Liu Xiaobo, Charter 08, and the Challenges of Political Reform in China (Hong Kong University Press, 2012).

118 See Peerenboom, China's Long March Toward Rule of Law (n 74 above).

119 Larry Catá Backer, 'The Party as polity, the Communist Party, and the Chinese Constitutional State: A Theory of State-Party Constitutionalism' (2009) 16(1) Journal of Chinese and Comparative Law 101-165. See also Larry C. Backer, 'A constitutional court for China within the Chinese Communist Party' (2010) 43 Suffolk University Law Review 593-624.

120 Backer, 'The Party as polity' (n 119 above), at 103.
} 
state power and popular accountability based on law." 121

The theory of state-party constitutionalism as applied to contemporary China takes as its point of departure the idea that the Chinese Communist Party (CCP) is constitutionally entrenched as the "party in power". ${ }^{122}$ Unlike political parties in liberal-democratic systems, the CCP is not merely one among several political parties, but is an integral and vital part of the state's constitutional, political and legal systems. Thus the real constitution of the PRC includes not only the Constitution of the PRC state, but also the constitution or Charter of the CCP. ${ }^{123}$ Insofar as the CCP promotes the Rule of Law, subordinates itself to the Rule of Law and engages in "self discipline" 124 for this purpose, and insofar as there is some form of "separation of powers"125 -- between the CCP (as the source of the values and fundamental policies that guide the government ${ }^{126}$ ) and the state organs (which engage in concrete administrative tasks), constitutionalism can be said to be practised in China. Such "state-party constitutionalism" is said to be a kind of "constitutionalism with Chinese characteristics". 127

This theory admits that in this kind of constitutionalism, not all citizens have "political citizenship" and exercise political rights, although all of them have "economic and social citizenship" and exercise economic and social rights. ${ }^{128}$ Political citizenship in China, according to this theory, is confined to members of the $\mathrm{CCP}$, whose membership is open to everyone who subscribes to its values and visions. ${ }^{129}$ The CCP as an updated version of the Leninist "vanguard" party ${ }^{130}$ represents the interest of the Chinese people, acts as their "proxy" and in a "fiduciary capacity", 131 and discharges "pedagogical and tutelage responsibilities". 132

The theory of "state-party constitutionalism" is useful for the purpose of studying the evolution ${ }^{133}$ of a communist party-dominated political system that gives up totalitarianism, withdraws itself from the control of many sectors of the economy, society and culture, concedes a large space for private life and private pursuits, seeks

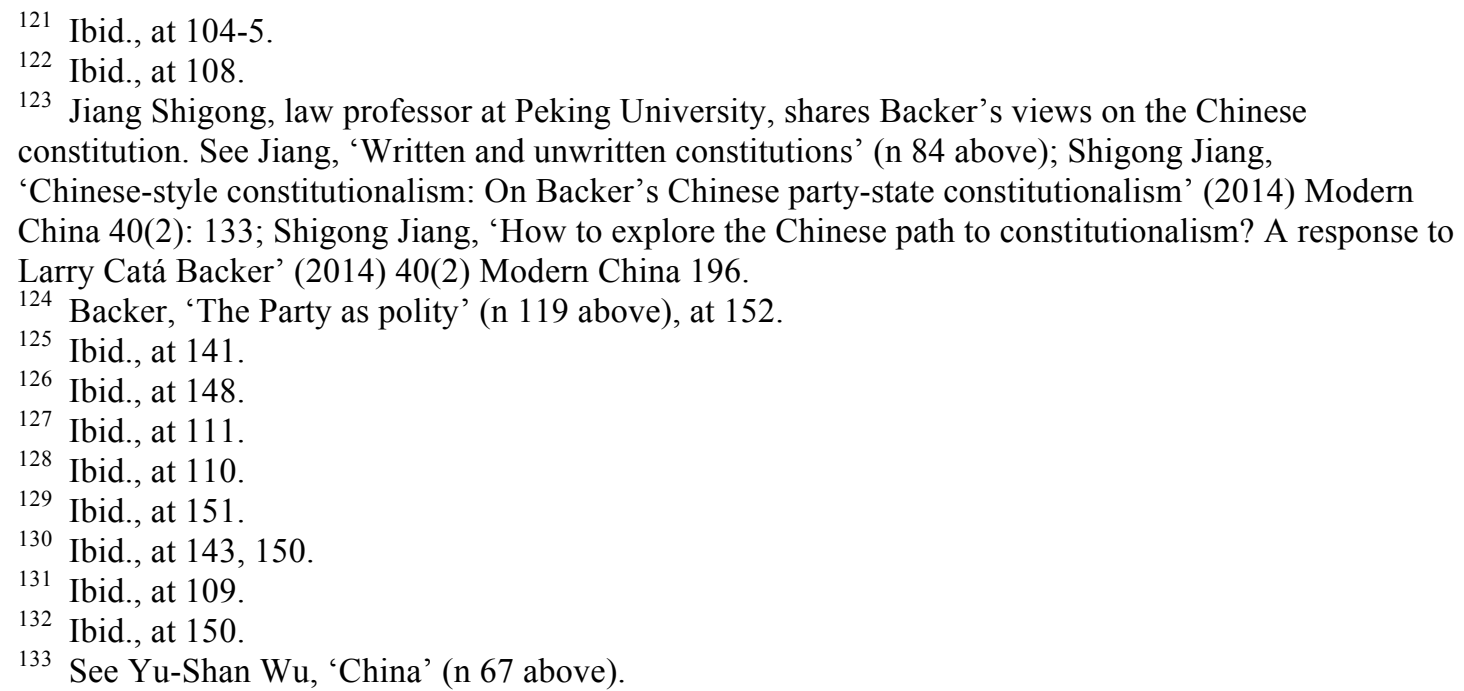


to regulate itself by the Rule of Law, and recognizes that citizens' rights should be afforded legal protection. The concept of state-party constitutionalism shares some of the features of hybrid constitutionalism as discussed above, particularly in terms of the adherence to the Rule of Law and legal restrictions on civil liberties, but differs from hybrid constitutionalism in that it does not permit any space for opposition political parties and multiparty elections.

Without such space, it may be questioned whether the portrayal of the role of the "party in power" in the theory of "state-party constitutionalism" is too idealized and too distant from the reality that despite the fact that the CCP has 89 million members today, its power is actually exercised by a small elite of Party leaders who are subject to little popular electoral accountability. The de facto lack of political citizenship on the part of the great majority of Chinese citizens as recognized by the theory also contradicts the text of the PRC Constitution itself, according to which all citizens have equal political rights. It is therefore doubtful whether this theory of state-party constitutionalism can fully legitimize the party-state itself.

Secondly, it may be queried whether the "separation of powers" between the $\mathrm{CCP}$ and state organs as identified by the theory is a sufficient separation of powers for the purpose of constitutionalism. It has been pointed out ${ }^{134}$ that the Chinese political system is characterised by a "dual normative system", ${ }^{135}$ i.e. the "cohabitation of two normative systems" Party organs such as the Central Committee of the CCP, its Politburo and the Politburo Standing Committee) and the State system (comprising institutions such as the National People's Congress, the State Council, courts and procuratorates). Among these two systems, only the State system is governed by the Constitution and laws of the People's Republic of China, while the Party system is governed by the Party's own constitution -- the Charter of the $\mathrm{CCP}$-- and its internal regulations and rules. Yet Party leaders and organs participate actively in and selectively intervene in the decision-making processes of State organs, ${ }^{137}$ acting behind the scenes and not being subject to the State's legal requirements of transparency and accountability or the possibility of being challenged in judicial review proceedings before the courts of the

\footnotetext{
${ }^{134}$ Ling Li, " "Rule of Law" in a Party-State: A conceptual interpretive framework of the constitutional reality of China' (2015) 2 Asian Journal of Law and Society 93-113.

135 Ibid., at 93, 96 .

136 Ibid., at 107.

${ }^{137} \mathrm{Li}$ points out that there exists a 'functional division of labor between the Party and the state'; 'this arrangement leads to the bifurcation of decision-making process in state institutions' (ibid., 96). '[S]tate decision-making has been bifurcated, with one phase taking place backstage, as it were, in the Party institution and the other taking place "onstage" in the state institution. The bridge between them is provided by the Party-groups installed in the decision-making bodies of state institutions, which are serving both the Party and the state' (ibid., 106).
} 
State. ${ }^{138}$ Insofar as State organs are subject to the control and direction of Party organs, it may be doubted whether there is some kind of genuine separation of powers or checks and balances within the Chinese political system that the concept of constitutionalism implies.

Furthermore, the study of CCP leadership as a core element of China's "living constitution"139 has shown that "there is no real division of power between the party and other state apparatuses. ... there only exists division of labour. ... There is no meaningful separation of power and independence among the state apparatuses and the party." a large state usually entails. For example, even though in practice local governments enjoy considerable autonomy and some kind of "de facto fiscal federalism"141 exists in China today, there is no "political division of power" between local and central authorities in a "constitutional sense". 142 The general picture seems to be that State organs and citizens in practice enjoy considerable powers and rights on sufferance, without any secure constitutional or legal protection against intervention by Party authorities. The CCP not only "defines what power ... state apparatuses may enjoy (content)"; "the CCP, as the ultimate decision-maker, decides which questions shall be decided by it (jurisdiction) and when it intervenes (timing)". ${ }^{143}$ But insofar the Party chooses not to intervene, "there remains room for innovation, development and power advancement for other state apparatuses and citizens' rights." 144

Thirdly, the theory of state-party constitutionalism in China is partly premised on the existence of the Rule of Law in China as a consequence of the development of the Chinese legal system in the last few decades. However, it may be queried whether, or to what extent, the Rule of Law exists in contemporary China. Critics and skeptics argue that despite the development of the Chinese legal system in the last few decades, China is at most practising or moving towards "Rule by Law", rather than practising or moving towards genuine "Rule of Law", ${ }^{145}$ because China is an authoritarian one-party state in which the supremacy of the CCP cannot be reconciled with or made compatible with genuine Rule of Law.

In this regard, the distinction between law-based legitimacy and ideology-based legitimacy is noteworthy. In the history of the establishment of the PRC, "ideological

\footnotetext{
138 Ibid., 106-111.

$139 \mathrm{He}$, 'The Party's leadership as a living constitution' (n 103).

140 Ibid., at 77.

141 Ibid., at 86,88 .

142 Ibid., at 87.

143 Ibid., at 92 .

144 Ibid., at 92.

145 See Peerenboom, China's Long March (n 74) at 130-141, on "specifying the minimum conditions for rule of law" and how to distinguish between Rule of Law and mere rule by law.
} 
commitment to socialism predates the constitutionalisation of the Chinese state". ${ }^{146}$ The legitimacy of rule by the CCP has been justified not by means of any constitutional document or constitutional mechanism or process, but by the ideology of Marxism-Leninism according to which the Communist Party, as vanguard of the proletariat, has the historical mission of leading the people in bringing about the revolution and in building a new socialist society.

Thus in a communist party-state, the position of the Communist Party leadership "is legitimized by superior insight in the ultimate aim of history and the true interest of the people. The legitimation principle is not consensus of the people, but an absolute truth." "147 In a political system "legitimized by an absolute truth", ${ }^{148}$ the constitution is subordinated to such truth. ${ }^{149}$ "The truth precedes the constitution and prevents it from being a comprehensive regulation of public power. The person or group of persons who embody or represent the truth, be it a priest or a group of clerics, be it a monarch or an avant-garde or a single political party that claims superior insight in the common best, remains above the constitution." "Law, constitutional law included, is reduced to an instrumental role. It regulates, limits, and guides the behaviour of the individuals and the inferior agents of the political system, not its leadership." "150

It is often said that in the PRC, the Constitution and the law are instruments of rule that add to the legitimacy of the party-state, but the Rule of Law is not realized. It has been suggested that the Chinese view -- or at least the CCP's view -- of law is quite different from law as understood in the Western tradition. The CCP “understands law as a reflection of the party's will and the people's will and a form of the party's and the people's self-discipline."151 The law does not "exist independently of politics." "152 According to this view, "[t]he socialist rule of law project is the party's and the people's effort to discipline themselves." never accepted the idea of the independent existence and supremacy of the constitution, ... There is no subordination of the party to the constitution and the laws. ... the party contends that it should, in a sense, stand above both. The party views itself as the guardian of the constitution and the laws, rather than just an ordinary political organization under the constitution. In the party's words, 'the

\footnotetext{
${ }^{146} \mathrm{He}$, 'Socialist Constitutionalism' (n 95 above) at 176.

147 Grimm, 'Types of constitutions' (n 5 above) at 128.

148 Ibid., at 129.

149 Ibid., at 114.

150 Ibid., at 114.

151 Xiaodong Ding, 'Law according to the Chinese Communist Party: Constitutionalism and socialist Rule of Law' (2017) 43(3) Modern China 322-352 at 322.

152 Ibid.

153 Ibid., at 324.
} 
leadership of the party is the most essential trait of socialism with Chinese characteristics, and is the most fundamental guarantee for socialist rule of law'."154

Hence it is argued that the nature and structural or systemic characteristics of the Party-State are such that, despite the considerable progress made in building a legal system in China in the post-Mao era, the Chinese legal system is not moving towards a system in which senior officials and top Party leaders who violate the law would be equally treated by the law and before the courts as others, and dissidents and others targeted by the regime would be accorded the same fair trials and due process that are accorded to others. In other words, even if China is making progress in extending some form of governance by law and adjudication in accordance with law in some domains of social and economic life, insofar as the Party reserves the right to intervene selectively in any "politically sensitive" matter or case relating to the Party's important interests and in which the Party leadership considers it necessary, expedient or desirable to intervene, the system cannot be regarded or described as "Rule of Law", because Rule of Law is the antithesis of arbitrary power. ${ }^{155}$

A move towards "socialist constitutionalism"? The question thus arises of the compatibility between the Rule of Law (as an essential ingredient of "state-party constitutionalism" as discussed above) and the supremacy of CCP rule. In this regard, the discourse in China in recent years of "socialist constitutionalism" "156 is instructive. A leading scholar who advocates "socialist constitutionalism" (shehuizhuyi xianzheng) is Tong Zhiwei. ${ }^{157}$ Unlike liberal scholars in China who do not agree that the monopoly of political power by the CCP is legitimate or should be given constitutional and legal recognition, Tong and other other adherents of "socialist constitutionalism" accept the political reality or even legitimacy of CCP rule in China, and seek to render it consistent with the Rule of Law or constitutionalism. Tong seeks to achieve this by proposing (a) to give constitutional and legal recognition to the ruling status of the $\mathrm{CCP}$, and (b) to introduce and implement constitutional and legal norms that define the scope of the power of Party organs (including the respective boundaries of the power of State institutions and Party organs) and personnel and subject such power to precise legal control, regulation and supervision. Such legal norms are almost completely absent in the existing system.

\footnotetext{
154 Ibid., at 329-330.

155 See generally Brian Z. Tamanaha, On the Rule of Law: History, Politics, Theory (Cambridge U Press 2004); Tom Bingham, The Rule of Law (Allen Lane 2010); Martin Krygier, 'Rule of Law', in Rosenfeld and Sajó (eds), Oxford Handbook (n 5 above) 233-249.

156 See He, 'Socialist Constitutionalism' (n 95 above).

157 Tong Zhiwei, Zhongguo xianzhi zhi weixin (The Renovation of China's Constitutional System) (City University of Hong Kong Press, 2016).
} 
Tong's proposals has not found favour with the authorities so far. Indeed, since 2013, the very use of the term “constitutionalism” (xianzheng 宪政) in public discourse has been suppressed by the authorities. ${ }^{158}$ In the circle of intellectuals and writers, advocates of socialist constitutionalism were opposed by both liberals and conservatives. Liberals ${ }^{159}$ believe in liberal democracy and oppose the idea of enshrining one-party rule in the Constitution and codifying it in various laws. On the other hand, conservatives ${ }^{160}$ believe that the existing political system - as a component of the "China Model" -- has served China well, and there is no need to subject the Party to the legal norms of the State.

A notable development that offers hope from the perspective of advocates of socialist constitutionalism in China is that the decision of the $4^{\text {th }}$ plenum of the $18^{\text {th }}$ CCP Central Committee in 2014 on "ruling the country according to law"161 advocated, inter alia, the strengthening of the system of rules and regulations governing the Party ("intra-Party regulations"), ${ }^{162}$ although there was no suggestion or intention to turn such rules and regulations into part of the laws and regulations of China's legal system, which - unlike Party rules and regulations -- are all enacted in accordance with the norms and procedures prescribed by China's Constitution and laws, publicly promulgated and enforceable before the courts of law. The plenum's call for the strengthening or further development of the existing system of "intra-Party regulations" has generated a lively scholarly discourse on the significance and even constitutional implications of the development of "intra-Party regulations" as a normative system consisting of rules and regulations enacted by Party organs in accordance with the Charter of the CCP, existing side by side with the legal norms enacted by State organs (such as the National People's Congress and its Standing Committee) in accordance with the Constitution of the PRC. ${ }^{163}$

A leading theorist of the possible direction of development of socialist constitutionalism in China is Ke Huaqing. ${ }^{164}$ He develops a typology of three forms

\footnotetext{
158 See the works cited in $\mathrm{n} 2$ above.

159 Such as Zhang Qianfan and He Weifang, both professors of law at Peking University.

160 Such as those opposed to the use of the term xianzheng (constitutionalism): see the works cited in $\mathrm{n}$ 2 above.

161 See Randall Peerenboom, 'Fly high the banner of socialist rule of law with Chinese characteristics!' (2015) 7 Hague Journal on the Rule of Law 49-74; Sanzhu Zhu, 'Socialist rule of law in the 21st century' (2015) 7 Hague Journal on the Rule of Law 75-81; Jianfu Chen, 'The transformation of Chinese law: Mark II' (2015) 45 Hong Kong Law Journal 911-939.

${ }^{162}$ See section 2 (on 'strengthening the construction of the system of intra-Party rules and regulations (dangnei fagui 党内法规)) of part 7 (on 'strengthening and improving the leadership of the Party with regard to the full promotion of ruling the country according to law') of the Decision.

${ }^{163}$ See Zhang, 'Rule of law within the Chinese party-state' (n 115 above); the symposium of Chinese articles on the relationship between intra-Party regulations and State law, in [2016] 3 Zhongguo falü pinglun (China Law Review) 21-51.

164 The following discussion of Ke's theory is based on the Chinese article, Ke Huaqing and Liu Rong, 'Lun lixian dangdao zhi' ('On constitutional Party leadership') [2015] 7 Zhanlüe yu guanli (战略与管理
} 
of constitutions or constitutionalism: constitutional monarchy; constitutional democracy; and constitutional Party leadership (lixian dangdao zhi, alternatively translated as "Party-led constitutional system"). In his view, the PRC is already practising a certain degree of constitutional Party leadership, but the political, constitutional and legal systems should be further developed and improved, so as to further institutionalize Party leadership, and to practise or constitutionalise more fully the system of constitutional Party leadership. This should be done by introducing a new chapter in the PRC Constitution that expressly provides for the leading status and role of the CCP (as a vanguard and progressive party representing the interests of the whole Chinese people), how it should perform its leadership functions, what powers it may exercise and how such powers may be exercised.

Ke describes the PRC constitutional system as a dual system based simultaneously on the PRC Constitution and the Charter of the CCP. He suggests that the constitutional and legal system of the PRC should evolve towards a threefold system consisting of (a) State laws, (b) intra-Party regulations and (c) laws and regulations on Party leadership (dangdao fagui 党导法规). As regards category (b), Ke considers that the rules and norms in the existing system of intra-Party regulations are less highly developed than the State laws of the PRC, and should therefore be further developed and strengthened in accordance with general premises of the Rule of Law. Furthermore, there should be an effective system to supervise the implementation of intra-Party regulations, including adjudicative bodies to apply and enforce the regulations in concrete cases.

Category (c) is a new concept invented by Ke. Whereas intra-Party regulations (category (b)) are made by Party organs and are only applicable to Party members and organs, category (c) consists of norms proposed by the CCP as Party policies or decisions but adopted by State organs such as the National People's Congress and its Standing Committee, so that they are binding on all persons and institutions. The nature of category (c) norms is such that they serve as a bridge between State laws and intra-Party regulations, and facilitate or manifest the exercise of the leadership functions of the Party.

The decision in the $4^{\text {th }}$ Plenum of 2014 to strengthen the system of intra-Party regulations suggests that it is possible that China will move in a direction closer to the kind of "constitutional Party leadership" envisaged by Ke. ${ }^{165}$ Such a move would

Strategy and Management) 1-86.

165 On the other hand, it has been suggested that the introduction into the Constitution of express or detailed provisions on CCP leadership might be very controversial and involve high "political cost", hence the more likely scenario is that the Chinese regime will "continu[e] to muddle through, setting aside ideological tensions, jurisprudential puzzles, and technical inconsistencies while adopting a results-oriented pragmatic approach that adjusts the multifaceted relationship between the Party and state on an ongoing basis through a combination of formal and informal rules, conventions, and 
give greater credibility to the thesis that China is moving towards some form of "state-party constitutionalism". Insofar as the essence of constitutionalism is, as suggested in part II of this chapter, the subjection of political power-holders to the governance of constitutional and legal rules, the system of "constitutional Party leadership" as theorized by Ke does seem to fulfil the core requirements of constitutionalism.

Ironically, any move of the Chinese party-state towards "constitutional Party leadership" or the kind of "communist/socialist constitutionalism" it embodies would mean a move in the opposite direction of liberal constitutionalism, and make it more difficult for China to achieve a gradual transition from the present system to a more liberal constitutionalism. Insofar as the constitutional and legal powers of the CCP are not formalized, institutionalized and fully legitimized and in the existing Constitution and laws of the PRC, the possibility exists, in both theory and practice, for more open and competitive elections to be introduced in the people's congress system, for the constitutional powers of the people's congresses and courts to be more actively exercised for the purpose of increasing the degree of accountability of officials and power-holders, and for a greater degree of freedom of speech and association to be allowed in the public sphere and civil society. There is little in the texts of the existing PRC Constitution and laws that prohibits or disallows such developments. The paradox therefore is that while it may doubted whether the existing political-constitutional-legal practices in the PRC meet the requirements of constitutionalism as constitutional and legal restraint on the exercise of State power and the subjection of political power-holders to the governance of constitutional and legal norms, a movement in the future towards a higher degree of constitutionalism in the form of "socialist constitutionalism" or "constitutional Party leadership" would take China further away from liberal constitutionalism.

\section{Conclusion}

This chapter has reviewed the development of the practice of adoption of written constitutions by states in the modern era, and discussed the global spread of such practice from Europe and North America to other parts of the world. It has considered the classifications or typology of constitutions and constitutionalism. It has examined the case of modern China from the perspective of constitutions and constitutionalism. The case of China offers much food for thought as we ponder the significance of written constitutions and the meaning of constitutionalism.

Learning from Western and Japanese constitutional models, the imperial government of the Qing Empire in the first decade of the $20^{\text {th }}$ century sought to move 
China in the direction of a constitutional monarchy. The plan did not materialize as Qing rule was overthrown by the 1911 Revolution which established the Republic of China. Experiments in constitution-making in the first decade of the republican era failed to produce any effective or stable constitution. The government established by the Kuomintang (KMT) in the late 1920's subscribed to a three-stage process of state-building: military rule; political tutelage (by the KMT); constitutional government (or constitutionalism). The Constitution of the Republic of China (RoC) adopted in late 1946, which was liberal-democratic in orientation, was supposed to inaugurate the era of constitutionalism in China. However, the Chinese Civil War of the late 1940's resulted in the KMT regime being driven to Taiwan where it imposed authoritarian rule. The liberal democratic promises of the RoC Constitution were only fulfilled after the KMT regime embarked upon liberalization and democratization by lifting martial law in 1987. Using the typology of constitutionalism developed earlier in this chapter, Taiwan was a case of "hybrid constitutionalism" subsequently moving towards liberal constitutionalism.

In mainland China, the establishment of the PRC by the Chinese Communist Party (CCP) in 1949 inaugurated a new era of constitution-making. Whereas the first constitution, enacted in 1954, largely followed the constitutional model provided by the Soviet Union, the constitution was blatantly disregarded in the Cultural Revolution era. In 1978, Deng Xiaoping launched the new policy of "reform and opening" and building a "socialism with Chinese characteristics", which included the reconstruction of the constitutional and legal systems. The progress made in developing the "socialist market economy" and the "socialist legal system with Chinese characteristics" raises the question of whether the PRC is practising or moving towards some form of "state-party constitutionalism".

The case of contemporary China thus poses the fundamental question of what is constitutionalism and how contemporary China should be located within a typology of constitutions or constitutionalism. This chapter suggests that the core requirement of constitutionalism is the subjection of power-holders to the governance of constitutional and legal norms. Whether constitutionalism is realised in a particular State at a particular time is a matter of degree. Constitutionalism is more fully realized where power-holders adopt the "internal point of view" (in H.L.A. Hart's words) towards constitutional and legal norms, where multiple powers check and balance one another, or where independent courts adjudicate on whether constitutional and legal norms have been complied with. Thus the Rule of Law is an indispensable ingredient of constitutionalism.

Insofar as the supreme power of the CCP has not been fully subordinated to the Rule of Law, it may be doubted whether constitutionalism - at least in the form of 
"state-party constitutionalism" -- is currently practised in China. However, theories propounded by scholars such as Tong Zhiwei and Ke Huaqing, if implemented, would bring China closer to some kind of constitutionalism, such as "socialist constitutionalism" as theorized by Tong or "constitutional Party leadership" as theorized by Ke. Ironically, a move of China towards constitutionalism of the kind envisaged by Tong and Ke would take China further away from liberal constitutionalism, and probably make a gradual transition to liberal constitutionalism in the future more difficult. 